DOCUMENTO HISTÓRICO: 1964

\title{
A REVOLUÇÃO DE 1964 E O MOVIMENTO MILITAR NO PARANÁ: A VISÃODA CASERNA
}

\author{
José Carlos Dutra
}

\section{RESUMO}

Neste trabalho apresenta-se um relato do golpe militar de 1964 conforme a visão da caserna. Como o movimento foi nacional, torna-se por vezes difícil destacar aspectos políticos ou militares regionais. Mesmo assim, procurou-se dar um enfoque local ao processo político, tendo por palco o estado do Paraná. O artigo resume a estrutura militar e a posição dos oficiais que serviam nas organizações militares do estado. A dinâmica do golpe é descrita a partir do ângulo de visão dos quartéis e traz, por meio de entrevistas, a opinião de três oficiais generais que tiveram participação ativa no movimento.

PALAVRAS-CHAVE: política brasileira; militares; populismo; militarismo; Paraná.

\section{INTRODUÇÃO}

A motivação dos militares para a revolução, tanto daqueles que ocupavam a cúpula da hierarquia - com projeção nacional, portanto quanto aqueles posicionados nas camadas intermediárias, com projeção regional, era a mesma. Pelo menos no discurso não foram identificadas razões diversas das já conhecidas no meio militar, quais sejam, quebra da hierarquia e da disciplina, caos social, corrupção e comunização da nação: resta saber como os oficiais que serviam nas chamadas Grandes Unidades e Grandes Comandos, como no caso do Paraná a $5^{\text {a }}$ Região Militar, viram o golpe. No presente trabalho traz-se o depoimento de três oficiais, hoje generais na reserva remunerada e que na época ocupavam os postos de oficiais intermediários e superiores em organizações militares de Curitiba, constituindo-se em partícipes ativos e observadores privilegiados dos acontecimentos. Antes, porém, pretende-se, a título de ambientação do leitor, discorrer sinteticamente acerca da estrutura militar no Paraná em 1964 e a posição adotada pelos militares que exerciam as principais funções de comando no estado - aqueles que, em razão do cargo, exerciam a liderança sobre a tropa.

\section{AESTRUTURADAS FORÇAS ARMADAS NA REGIÃO SUL}

Considerando-se que das três Forças o Exército é a que possui o maior efetivo, havia uma predominância da força terrestre na região, sendo o estado do Rio Grande do Sul o mais militarizado. A estrutura militar na década de 1960 era basicamente a que existe hoje, à exceção de algumas unidades criadas e outras transferidas desde então. O Paraná possuía um efetivo militar bem menor que o gaúcho, concentrado basicamente na capital e na região Centro-sul do estado. Em Curitiba encontrava-se a sede do Comando da $5^{\text {a }}$ Região Militar e $5^{\text {a }}$ Divisão de Infantaria ( $\left.5^{\mathrm{a}} \mathrm{RM} / \mathrm{DI}\right)$, hoje $5^{\mathrm{a}}$ Região Militar e $5^{\mathrm{a}}$ Divisão de Exército ( $5^{\mathrm{a}} \mathrm{RM} /$ DE), com jurisdição sobre os estados do Paraná e Santa Catarina e subordinada ao então III $^{\circ}$ Exército (hoje Comando Militar do Sul), com sede em Porto Alegre e jurisdição sobre os três estados do Sul. A $5^{a} \mathrm{RM} / \mathrm{DI}$ possuía em seu território comandos subordinados (artilharia divisionária, brigadas de infantaria, regimentos e batalhões de infantaria, grupos de artilharia, regimentos de cavalaria e unidades de apoio). Essas unidades não eram bem distribuídas territorialmente, pois havia uma extensa região totalmente desmilitarizada (todo o Norte e o Sudoeste do estado).

O território paranaense, constituído por uma faixa de terras relativamente estreita, tendo de um lado o Oceano Atlântico e de outro a fronteira com Argentina e Paraguai, com baixa densidade demográfica e quase nenhuma proteção militar, formava um corredor propício à progressão de tropas militares. Devemos lembrar que esse espaço geográfico foi utilizado para o avanço das tropas de Gumercindo Saraiva, na Revolução Federalista, no final do século XIX, culminando com o histórico

Rev. Sociol. Polít., Curitiba, 22, p. 195-208, jun. 2004 195 
cerco da Lapa. Luiz Carlos Prestes igualmente avançou sobre o território paranaense com a sua Coluna por Sudoeste e Oeste até embrenhar-se nas selvas bolivianas. O fato repetiu-se em 1932 durante a Revolução Constitucionalista e, por fim, a mesma estratégia foi posta em prática pelo Coronel Cardim Osório no frustrado atentado ao Marechal Castello Branco, quando, com o seu grupo,avançou pelo Sudoeste do estado e foi derrotado na região de Leônidas Marques e Francisco Beltrão ${ }^{1}$.

O Paraná, portanto, pela sua posição geográfica, constituía-se em ponto estratégico importante, pois representava o divisor entre as tropas do Rio Grande, sempre dispostas à ação, e o restante do país, servindo como uma barreira à progressão em direção ao Sudeste e o Centro brasileiros. A falta de um contingente militar bem distribuído no território paranaense tornava vulnerável os estados de São Paulo e Rio de Janeiro.

A baixa densidade militar no estado não oferecia as mesmas condições de organização para a conspiração como ocorria em São Paulo, Rio de Janeiro e Rio Grande do Sul. Talvez por essa razão justifique-se o pequeno envolvimento dos militares paranaenses com a cúpula revolucionária, o que, por outro lado, não autoriza afirmar que esses militares estiveram alheios ao processo, conforme se verá, principalmente a oficialidade.

\section{A POSIÇÃO DOS MILITARES}

Os militares no Paraná encontravam-se divididos, particularmente a oficialidade. De um lado, os "janguistas", que pregavam a posse de Jango e a devolução dos poderes presidenciais suprimidos pelo parlamentarismo. De outro lado, aqueles que não viam com bons olhos o desenrolar dos acontecimentos, principalmente a agitação política que terminou contaminando a caserna, além de produzir graves problemas de indisciplina. As punições disciplinares impostas aos militares eram constantemente anuladas por ordem do Ministro da Guerra.

\footnotetext{
1 O Coronel Cardim Osório estava refugiado no Uruguai onde, com o auxílio não confirmado de Leonel Brizola, reuniu um pequeno grupo de seguidores e adentrou o Rio Grande do Sul. Na divisa com Santa Catarina tomou um posto policial, obtendo armas e munições. Seu objetivo era chegar a Foz do Iguaçu por ocasião da inauguração da Ponte da Amizade, a cujo evento compareceria Castello Branco, contra quem pretendia promover um atentado.
}

A situação começava a fugir do controle. Exemplo disso foi o episódio em que o Comandante do $\mathrm{III}^{\circ}$ Exército, partidário de Jango, oficiou ao Ministro da Guerra e distribuiu cópia aos comandos subordinados, informando ser incapaz de manter a ordem no Sul. O General Ernesto Geisel, à época Comandante interino da $5^{\mathrm{a}} \mathrm{RM} / \mathrm{DI}$, de maneira enérgica e contrariando seu superior hierárquico, comunicou-lhe que estava em condições de manter a ordem no Paraná e em Santa Catarina. Tal ousadia custou-lhe a exoneração do cargo, sendo deslocado para uma função burocrática no Rio de Janeiro. Em seu lugar foi nomeado um general alinhado com o Comandante do $\mathrm{III}^{\circ}$ Exército, o que desagradou parte da oficialidade que servia em Curitiba.

A crise provocada pela renúncia de Jânio e a intolerância à posse de João Goulart repercutiu no comando militar do Paraná. No auge da crise, comandava a $5^{\mathrm{a}} \mathrm{RM} / \mathrm{DI}$ o General Benjamin Rodrigues Galhardo, que, no dia 28 de agosto de 1961, procurou o Governador Ney Braga e disselhe que era capaz de garantir a posse do General Cordeiro de Farias no cargo de Comandante do $\mathrm{III}^{\circ}$ Exército, em seu quartel-general (atual Solar do Barão). No dia 31 de agosto mudou de posição, passando a apoiar o General Machado Lopes e declarando que as tropas do Ministro da Guerra não passariam pelo Paraná, que, segundo ele, era a fronteira da legalidade ${ }^{2}$. Esse episódio demonstra bem a confusão que reinava naqueles dias.

O ambiente militar começou a ficar conturbado no ano de 1963, complicando-se ainda mais com a decisão do Supremo Tribunal Federal de declarar a inelegibilidade dos sargentos. A despeito dessa decisão, o Partido Trabalhista Brasileiro (PTB) lançou a candidatura de um Subtenente ao cargo de Vereador em Curitiba, o que a oficialidade considerou uma afronta. É preciso lembrar que o diretório municipal daquele partido era dirigido pelo

2 O Comandante do $\mathrm{III}^{\circ}$ Exército fôra destituído do cargo, mas recusou-se a entregá-lo ao substituto, General Cordeiro de Farias, sublevando as tropas do Rio Grande do Sul e obrigando o Presidente da República a extinguir o $\mathrm{III}^{\circ}$ Exército e considerar suas tropas como rebeldes e amotinadas. Foi determinado ao General Cordeiro de Farias que constituísse um grande destacamento militar que se deslocaria do Rio de Janeiro para o Rio Grande do Sul, com a missão de prender o general rebelde, dominar a situação e tomar posse no cargo. Contava para tanto com o apoio da $5^{\mathrm{a}} \mathrm{RM} / 5^{\mathrm{a} D I}$ - daí a razão das declarações do seu Comandante. 
Coronel Barcelos, Comandante do Centro de Preparação de Oficiais da Reserva (CPOR), localizado na Praça Oswaldo Cruz (hoje Shopping Curitiba). Naquela unidade militar ocorriam reuniões políticas e acalorados debates sobre a situação política do país. Essa situação era considerada inadmissível, principalmente pelos oficiais revolucionários, que entendiam que a situação dos militares não era compatível com a atuação política.

A partir de setembro de 1963 a situação tornouse ainda mais complicada para os revolucionários, uma vez que assumiu o Comando da Infantaria Divisionária de Ponta Grossa o General Chrysantho de Miranda Figueiredo, conhecido apoiador do programa reformista do governo federal, que defendia publicamente. Assumiu o Comando da $5^{\mathrm{a}} \mathrm{RM} / \mathrm{DI}$, nessa mesma época, o General Silvino Castor da Nóbrega, que, se não pregava abertamente, de maneira velada defendia as posições do Presidente da República. Outros comandantes já eram tidos como de esquerda, uma vez que, pela participação em atividades políticas, aproximavam-se de líderes partidários de esquerda - como era a situação do Comandante do CPOR, do $13^{\circ}$ Regimento de Infantaria de Ponta Grossa e de outros -; em virtude de suas posições, colocavam-se em rota de colisão com os demais oficiais nacionalistas e revolucionários.

Na visão da caserna havia uma clara e iminente possibilidade de "comunização" do país. Em razão disso, já existia uma grande preocupação com a doutrinação dos militares. Houve intensificação de palestras, cursos e treinamentos sobre movimento comunista internacional, guerra revolucionária e movimentos subversivos. Houve também uma preocupação com a estruturação de um sistema de inteligência militar, apesar de já existir, no Exército, uma boa rede de informações e contra-informações. Os militares já acompanhavam as atividades dos políticos e dos próprios companheiros considerados de esquerda, que foram mapeados e suas atividades passaram a ser monitoradas. Sob esse aspecto, pode-se dizer que os militares não foram apanhados de surpresa, pois detinham um grande volume de informações sobre aqueles que consideravam comunistas. Nesse sentido, as esquerdas subestimaram o trabalho de inteligência desenvolvido pelos militares ou estavam mal informadas acerca da preparação das Forças Armadas. Essa assertiva é corroborada pela análise dos documentos produzidos pelo Estado-Maior do Exército, que na ocasião era chefiado pelo General
Castello Branco (ESTEVES, 1996), que relatam a preocupação dos chefes militares com um sistema de informações e contra-informações, destacandose a criação do Serviço de Informações e ContraInformações do Exército (SICIE), precursor do Centro de Inteligência do Exército (CIE).

\section{A DINÂMICA DO GOLPE SEGUNDO A VISÃO DA CASERNA}

$\mathrm{Na}$ época o Paraná era governado por Ney Braga, de origem militar (Coronel), eleito pelo Partido Democrata-Cristão (PDC). Apesar de possuir apoio da maioria, havia focos de descontentamento dentro do governo, uma vez que, para assegurar a governabilidade, alguns postos da administração estadual foram entregues a políticos de tendências esquerdistas. A cúpula militar sediada no estado acreditava que no momento apropriado o Governador saberia como agir no sentido de neutralizar esses políticos; todavia, à medida que passava o tempo, a indefinição de Ney Braga começou a causar preocupações aos conspiradores, pois sabiam que a posição a ser por ele adotada influenciaria decisivamente o desfecho do golpe (como de fato confirmou-se depois).

O ano de 1964 começou com grande agitação nos quartéis. A insubordinação dos sargentos da Marinha foi um duro golpe na hierarquia e na disciplina de toda a Força, uma vez que essas notícias espalhavam-se como rastilhos de pólvora pelas unidades militares, de Norte a Sul. Setores da elite política começaram a bater às portas dos quartéis solicitando providências. O Governador Ney Braga foi à televisão e fez um pronunciamento contra o que chamava de "baderna". Supõe-se que esse pronunciamento seria a prova de que os militares precisavam para terem certeza dos propósitos de Braga, pois havia, no meio político, comentários de que ele não era um revolucionário de primeira hora. Depois do pronunciamento ninguém mais teve dúvidas do lado em que estava. Isso tranqüilizou sobremaneira os militares. Se a situação previamente já estava ruim, tornou-se ainda pior com a atitude do Presidente Goulart de reunir-se com os sargentos no Automóvel Clube, no Rio de Janeiro, à revelia dos comandantes militares.

No dia 29 de março o Comandante interino da $5^{\mathrm{a}} \mathrm{RM} / \mathrm{DI}$ resolveu, em face da gravidade da situação, convocar todos os coronéis em serviço na guarnição de Curitiba para uma reunião. Houve unanimidade entre os presentes na determinação 
de assegurar a disciplina em qualquer circunstância, manter a hierarquia e combater o comunismo. Não se falou em golpe nessa reunião.

Na noite do dia 30 de março Ney Braga procurou, reservadamente, o Comandante da $5^{\text {a }}$ RM/DI, após retornar de Belo Horizonte, onde se avistara com o Governador mineiro Magalhães Pinto. Na oportunidade o Governador do Paraná manifestou integral simpatia pelo movimento que se desencadearia em Minas Gerais e fez entrega de uma carta de apelo do General Guedes, no sentido de que o General Dario Coelho se juntasse aos seus companheiros mineiros.

O 31 de março, no Paraná, transcorreu em meio a informações desencontradas e boatos de toda ordem, transmitidos pelas emissoras de rádio. $\mathrm{Na}$ tarde desse dia as tropas do Paraná receberam ordens superiores para entrar no regime de prontidão rigorosa, o que de fato ocorreu.

A elite militar no estado desconhecia a real situação ${ }^{3}$. Os oficiais sabiam que algo aconteceria, mas desconheciam o dia e a forma dos acontecimentos. Tenta-se explicar essa desinformação dos militares do Paraná de duas formas: a primeira sustenta que, na verdade, essa desinformação era generalizada, à exceção de poucos oficiais generais da cúpula militar - como Mourão, Guedes, Castello Branco e Kruel -; ou seja, a decisão de intervir, naquele dia, partiu de um pequeno grupo, havendo uma adesão rápida da maioria dos comandantes. A outra forma de explicar a desinformação dos militares seria o fato de o Paraná estar fora dos centros de decisão, uma vez que a conspiração foi deflagrada em Belo Horizonte, com repercussões imediatas em São Paulo, Rio de Janeiro, Brasília e Porto Alegre. Somente em um segundo momento houve preocupação do comando revolucionário com o aparato militar do Paraná.

As primeiras notícias que chegaram ao estado davam conta de uma rebelião das tropas federais aquarteladas em Minas Gerais, a serviço de um golpe liderado por Carlos Lacerda e Adhemar de Barros. Tal notícia não teve uma boa acolhida pela oficialidade paranaense, uma vez que esses políticos não eram bem vistos pelos militares. Esse fato causou dúvidas em alguns oficiais quanto à

3 Isso demonstra que não houve um planejamento, uma preparação, não havia um "Dia D" para a eclosão do movimento. posição que deveriam adotar em relação aos acontecimentos. Essa incerteza ficou patente nas sucessivas reuniões de comando realizadas na noite de 31 de março e durante o dia $1^{\circ}$ de abril, quando todos os oficiais que serviam na guarnição militar de Curitiba foram chamados ao quartel-general da $5^{\mathrm{a}} \mathrm{RM} / \mathrm{DI}$ e o Comandante interino ${ }^{4}$ indagou-os sobre a posição de cada um no episódio, ou seja, de que lado estavam. Confirmada a informação de que se tratava de um movimento militar contra "o comunismo, a corrupção e a quebra da disciplina", a adesão foi quase total. Um documento denominado Relatório da $5^{a}$ Região Militar e $5^{a}$ Divisão de Infantaria concernente ao movimento militar de 31 de março de 1964, relata a prisão, por discordarem da posição assumida pelo Comandante, dos tenentes-coronéis Paulo de Moraes e Flávio Dias de Castro - ambos ocupavam funções administrativas no Comando da $5^{\text {a }}$ Região Militar. O mesmo documento relata, também, a prisão do Coronel Alcides do Amaral Barcelos e do TenenteCoronel Edson Giordano de Medeiros, ambos do CPOR sob a acusação de exercerem militância política em partidos de esquerda, em que defendiam abertamente as reformas governistas e por terem discordado da posição adotada pelo General Dario.

O levante das tropas de Minas Gerais teve o apoio imediato do $\mathrm{II}^{\circ}$ Exército, sediado em São Paulo. O apoio do Comandante interino da $5^{\mathrm{a}} \mathrm{RM} /$ DI às tropas mineiras e paulistas significou o rompimento militar do Paraná e Santa Catarina com o Rio Grande do Sul, posicionando-se, portanto, contra o seu superior hierárquico, o Comandante do III $^{\circ}$ Exército e, consequientemente, contra o governo estabe-lecido. Retomando o encontro de Ney Braga com o Comandante da Região Militar, ocorrido no dia 30 de março: podemos concluir que a adesão de ambos ao golpe fôra tomada de véspera, em razão da carta enviada pelo General Guedes, que, juntamente com o General Mourão Filho, deu início ao movimento em Minas Gerais.

O General Silvino, Comandante efetivo da Região Militar, dividia opiniões: alguns consideravam-no muito próximo das esquerdas e defensor das reformas propostas pelo governo; outros consideravam-no um militar extremamente

\footnotetext{
4 O Comandante efetivo, general Silvino, encontrava-se em férias no Rio de Janeiro; interinamente ocupava o cargo o general Dario Coelho.
} 
profissional, disciplinado e legalista. Era ex-combatente da $2^{\mathrm{a}}$ Guerra Mundial e, segundo algumas opiniões, não muito dado às questões políticas. $\mathrm{O}$ General deslocou-se do Rio de Janeiro na noite de 31 de março com destino a Curitiba com o intuito de reassumir o Comando da $5^{\mathrm{a}} \mathrm{RM}$. Essa notícia causou preocupações aos oficiais conspiradores, uma vez que era certa a sua adesão ao governo, o que poderia desencadear luta armada no estado. A solução encontrada foi desviar a aeronave para Porto Alegre, sob a alegação de impossibilidade de pouso na capital paranaense. Para tanto, houve tratativas do Comandante interino com o Governador do Estado e com o Comandante da Base Aérea de Curitiba, sendo que um tenente ficou encarregado de comunicar o fato ao piloto, quando da aproximação ao Aeroporto do Bacacheri, e dessa forma foi feito.

A preocupação com a chegada do General Silvino a Curitiba era tamanha que, além da providência de desviar a aeronave, foi despachado, às pressas, para o Rio de Janeiro, um coronel amigo e confidente do General, com o intuito de demovêlo da idéia de retornar a Curitiba. Tal missão foi infrutífera uma vez que, em virtude das dificuldades encontradas no trajeto, o emissário chegou ao destino quando o General já estava em Porto Alegre.

Da capital gaúcha o General Silvino tentou organizar uma resistência dando ordens aos batalhões de Blumenau e Joinvile para que se deslocassem na direção de São Paulo. Tal ordem não foi cumprida e o General foi destituído do Comando, acusado de apoiar os comunistas. Respondeu a inquérito policial-militar e, posteriormente, foi transferido para a reserva remunerada.

Em razão desses acontecimentos e devido ao fato de o Comandante do $\mathrm{III}^{\circ}$ Exército, General Ladario Pereira Teles, ter apoiando Brizola e Goulart, o Comando da $5^{\mathrm{a}} \mathrm{RM} / \mathrm{DI}$ e todas as unidades militares do Paraná e Santa Catarina foram retiradas da subordinação a Porto Alegre, passando a integrar o $\mathrm{II}^{\circ}$ Exército, com sede em São Paulo, sob o comando do General Amaury Kruel, um dos líderes da revolução.

Apesar de o Paraná não estar no epicentro dos acontecimentos, por pouco não foi palco de luta armada. Devido aos fatos relacionados ao Comandante da $5^{\mathrm{a}} \mathrm{RM} / \mathrm{DI}$, acima narrados, o Comandante do $\mathrm{II}^{\circ}$ Exército determinou o deslocamento de tropas paulistas em direção à
Curitiba pela rodovia Regis Bitencourt, prevendo a possibilidade de confronto com as tropas do General Silvino e considerando, também, ser passagem obrigatória de tropas que poderiam vir do Rio Grande do Sul (o que não aconteceu devido ao domínio rápido da situação pelos revolucionários). Ainda assim, uma unidade militar foi deslocada de Itu, em São Paulo, para Curitiba e ali ficou por um determinado período.

\section{O GOLPE NA OPINIÃO DOS MILITARES}

Se a pesquisa em fontes secundárias é importante, para o estudioso de qualquer tema nada substitui a busca das informações diretamente nas fontes primárias. Daí se pode extrair a "matéria-prima" que pode ser, depois, trabalhada, analisada e interpretada pela Sociologia Política.

Desse modo, a seguir serão apresentadas as opiniões de alguns militares que participaram ativamente do golpe militar de 1964, pois ocupavam cargos importantes no Paraná. Foram entrevistados os generais: Raymundo Negrão Torres, oficial combatente da arma de artilharia, hoje na reserva remunerada e na época da revolução Major; fazia parte do Estado-Maior do Comando da $5^{\text {a }}$ Região Militar e $5^{\text {a }}$ Divisão de Infantaria, além de ocupar o importante cargo de Chefe da Seção de Informações; Ítalo Conti, ex-combatente da $2^{\mathrm{a}}$ Guerra Mundial, em que lutou na Itália como integrante da Força Expedicionária Brasileira (FEB), no posto de Capitão; à época da revolução possuía o posto de Coronel e ocupava o cargo de Secretário de Segurança do Estado do Paraná; por fim, Justo de Moraes, que possuía o posto de Capitão da arma de artilharia, ocupava o cargo de AjudanteGeral (responsável pela área de pessoal) do Comando da Artilharia Divisionária, com sede em Curitiba. A seguir transcrevem-se as entrevistas concedidas por esses oficiais ao autor.

$$
\text { * * * }
$$

Pergunta: O que ocorreu no Brasil, no dia 31 de março de 1964? Na opinião do senhor foi uma revolução, um golpe, uma insurreição ou apenas uma intervenção legal do Exército, no cumprimento de sua missão constitucional? O senhor pode justificar?

General Negrão: O que ocorreu em $31 \mathrm{de}$ março de 1964 foi um contragolpe, pois as Forças Armadas - atentas à sua missão constitucional de defesa das instituições democráticas - saíram dos quadros da legalidade, em um movimento cívico-mili- 
tar, para abortar uma situação que se desenhava claramente como um golpe da esquerda mancomunada com a autoridade legal que se estava tornando ilegitima pelas atitudes tomadas. Ver o capítulo 1, "A marcha da insensatez", em meu livro Nos "porões" da ditadura [TORRES, 1998, p. 24-28].

Gal. Ítalo: Em 1964, o que ocorreu foi uma ação preventiva, com as características de um golpe de Estado.

Gal. Justo: Na minha opinião o que ocorreu foi uma contra-revolução. O que aconteceu, na verdade, foi uma intervenção das Forças Armadas com maciço apoio da sociedade civil, principalmente das mulheres e da Igreja, para evitar que a esquerda tomasse conta do poder. Como justificativa principal cito o fato de não ter havido uma preparação meticulosa e uma liderança única que coordenasse a ação dos diversos grupos que conspiravam contra o governo do sr. Goulart.

P.: Existem algumas teorias sobre as razões que levaram os militares a intervir. Dentre elas destacam-se: iminência de uma revolução socialista; caos econômico e social; desestruturação das Forças Armadas; quebra da hierarquia e da disciplina. Gual a opinião do senhor a respeito dessas teorias?

Gal. Negrão: Não são teorias, são razões baseadas em fatos documentados com depoimentos posteriores, inclusive de escritores comunistas, como Jacob Gorender em seu livro Combate nas trevas. Dessas razões, a mais forte e que justificou a quase unanimidade [militar], foi a tentativa de desestabilização das Forças Armadas pela quebra da hierarquia e da disciplina. Ver o capítulo "Porque Jango caiu" em Nos "porões" [idem, p. 30-36].

Gal. Ítalo: As razões que levaram ao golpe foram as decisões do governo João Goulart, incapaz de evitar certos acontecimentos que convenceram grande parte das Forças Armadas de que um golpe institucional estava sendo preparado para a implantação de uma república sindicalista - o que seria a preliminar da tomada do poder pelo Partido Comunista. O comportamento do Presidente, confraternizando com sargentos e marinheiros em atos de total indisciplina, revelava uma violenta quebra da hierarquia militar.

O episódio do Almirante Braga sendo carregado efusivamente, por marinheiros sublevados, sendo ele o Comandante dos Fuzileiros Navais, convenceu até os que repudiavam o movimento - pois nele só viam aspectos políticos -, de que alguma atitude devia ser tomada, para pôr um paradeiro na anarquia reinante.

Gal. Justo: Considero que todas as razões citadas contribuíram para a intervenção militar. No entanto, o motivo que levou a maioria dos militares a participarem do movimento de 31 de março de 1964 foi a quebra da hierarquia e da disciplina, aliada ao clamor popular.

P.: Quando começou, de fato, a revolução (golpe, insurreição, intervenção) de 1964? Houve planejamento e preparação - isso era discutido nos quartéis - ou apenas o alto escalão das Forças Armadas é que tinha conhecimento das ações?

Gal. Negrão: Ver o "Prólogo" de meu livro 1964 - uma revolução perdida [TORRES, 2002, p. 1-4]. Alguns setores começaram a conspirar muito antes, logo depois do sucesso do Movimento da Legalidade e do plebiscito de janeiro de 1963. O alto escalão das Forças Armadas era governista e assim aliado de Jango. Havia alguns generais entre os conspiradores, mas estavam em funções secundárias.

Gal. Ítalo: O movimento de 1964 teve antecedentes longínquos. Suas raízes estão em 1935, ano da Intentona Comunista que deixou marcas profundas de repulsa à ideologia em várias gerações do Exército. Atingiu, principalmente os cadetes da Escola Militar do Realengo dos anos de 1935 1936 e 1937. A crueldade dos comunistas, assassinando companheiros militares, alguns até dormindo, como aconteceu na Escola de Aviação no Campo dos Afonsos no Rio de Janeiro [capital], atingiu o cerne daquela mocidade. Acrescente-se a isso a doutrinação realizada pelo Estado Novo, sob a ditadura de Getúlio Vargas.

Nunca houve uma convenção nacional para a preparação do movimento. Havia grupos em várias regiões que articulavam, mas nunca se chegando a conclusões sobre de que forma poderiamos iniciar o movimento. Muitas idéias surgiam, inclusive daqueles que achavam que o melhor era esperar uma decisão para ver como se comportaria a sociedade.

Como participante da FEB, acredito que a geração que deu os capitães para a 
campanha da Itália veio com um pensamento democrático muito acentuado. Isso influenciou os acontecimentos. Como Secretário de Segurança eu participava de reuniões com militares envolvidos no movimento, naturalmente com as devidas cautelas. Não eram muitos os mais comprometidos; acredito que o núcleo não passava de dez militares, entre tropa e Estado Maior. Participei de encontros com o General Cordeiro de Farias e o General Itiberê Gouveia do Amaral e alguns coronéis subscritores do famoso Manifesto dos Coronéis de 1954.

Gal. Justo: A preparação começou a intensifi-car-se após a renúncia de Jânio Guadros e a posse de João Goulart na Presidência da República. Pequenos grupos de civis e militares conspiravam em diversas regiões do país. Não percebi a existência de planejamentos e preparações centralizadas. Faziam-se alguns comentários sobre a situação política, mas não com intensidade e freqüência que pudessem prejudicar as atividades militares.

P.: O senhor foi apanhado de surpresa? Qual o nível de informações que possuía acerca dos acontecimentos daquela época?

Gal. Negrão: De certa forma, sim. Eu era o E-2 5 da $5^{\text {a }} \mathrm{RM} / \mathrm{DI}$ e tinha conhecimento da pregação esquerdista do General Crisanto e do alertamento, em sentido inverso, do General Dario em suas visitas às unidades [militares] contra as ações do governo. Ver meu relato em Meninos, eu "também" vi! [TORRES, 1999].

Gal. Ítalo: Eu, pessoalmente, fui surpreendido pelo início do movimento. Apesar dos preparativos, acreditava que as próximas eleições modificariam o quadro e não haveria necessidade de apelar para as armas. Isso porque as campanhas civis tinham como líderes pessoas de destaque como Carlos Lacerda e Magalhães Pinto.

As informações que nos chegaram vinham por intermédio de emissários, algumas desencontradas; entre esses emissários recebi o então Coronel João Batista de Figueiredo, depois Presidente da República. - Qual foi a mensagem do Gal. Figueiredo? -

5 "E-2" significa Segunda Seção do Estado-Maior; é a seção que trata da inteligência militar, informações e contrainformações.
Apresentou-me ele um panorama geral da situação do país e a adesão ao movimento.

Gal. Justo: Poucos militares foram apanhados inteiramente de surpresa. No dia 13 de março de 1964 foi realizado o comício da Praça da República, ao lado do Ministério da Guerra; no dia 25 de março ocorreu a rebelião dos marinheiros no Rio de Janeiro; no dia 30 de março, uma reunião de sargentos, no Automóvel Clube do Rio de Janeiro, com a participação do Presidente da República, ministros militares e conhecidos líderes comunistas. Espantados com o rápido desenrolar dos acontecimentos, com o crescimento das esquerdas, com a quebra da disciplina e empurrados pelo povo, a quase totalidade dos militares sentiu que havia chegado a hora de fazer alguma coisa para impedir a ruptura violenta da ordem e a implantação de um governo comunista no país.

P.: Havia confiança nos chefes militares? Houve adesão total ou ocorreram dissidências? Qual foi o tratamento dado aos dissidentes?

Gal. Negrão: Na 5a RM houve praticamente unanimidade. No QG [quartelgeneral] só dois oficiais declaram-se contra e foram presos. O comandante e o subcomandante do CPOR de Curitiba também se declararam e foram presos. Foram reformados em conseqüência do AI-1 [Ato Institucional n. 1]. Nesse particular, a atitude de Getúlio Vargas em 1930 foi mais inteligente, pois tentou atrair os que não apoiaram a revolução - e a maioria do Exército ficou nessa posição - e só com o Estado Novo [em 1937] aplicou punições aos dissidentes da época. Em 1964, não houve distinção entre os que não se solidarizaram com o movimento por convicção legalista e os que eram mancomunados com a baderna ou eram mesmo comunistas. Assim. houve alguns casos de injustiça nas punições.

Gal. Ítalo: Havia confiança em alguns altos chefes militares. Castello Branco, por exemplo, não conspirava, mas tínhamos certeza de que na hora decisiva estaria do nosso lado. A adesão não foi total no primeiro momento. No Rio Grande do Sul, por pouco não houve um choque de conseqüências imprevisiveis para o movimento. A atitude do General Pope Figueiredo permitiu ao General Ladário Teles, mandado 
pelo Presidente Goulart, que assumisse o Comando do III $^{\circ}$ Exército.

Após o movimento todos aqueles militares que, por atos ou palavras, tentaram impedir o movimento, foram cassados, com base no Ato Institucional n. 1. Posicioneime desde o primeiro momento favorável à revolução, apesar de achar que poderia haver uma saída política para a crise.

Gal. Justo: Os principais chefes militares da revolução gozavam de grande prestígio junto à tropa. No Paraná a adesão foi quase total. Os poucos oficiais e sargentos que não concordavam com o movimento apresentaram-se no $\mathrm{GG}$ da $5^{\mathrm{a}}$ Região Militar para ficarem presos. A maioria deles foi mandada de volta para casa. Os que continuaram presos foram tratados com camaradagem e de acordo com as normas regulamentares.

P.: Como era o clima nos quartéis? Havia indisciplina, ocorreram insubordinações. rebeliões ou motins?

Gal. Negrão: Não, em decorrência da confiança nos chefes. Os poucos que se dispunham a reagir ficaram sem uma liderança.

Gal. Ítalo: Nos quartéis, em alguns principalmente no Rio de Janeiro, o clima era tenso. Na maioria era de vigilância recíproca. A indisciplina, que eu saiba, foi somente em Brasília, com um motim de sargentos da Aeronáutica, que foi facilmente controlado.

Gal. Justo: Nos quartéis da 5 a Região Militar as atividades administrativas e de instrução da tropa corriam normalmente, com inteiro respeito às normas em vigor. A única organização militar que fugia a esse padrão era o antigo CPOR de Curitiba. Seu Comandante pertencia a um grupo de oficiais que apoiava inteiramente a política do Presidente da República. Em conseqüência, havia constantes debates políticos entre os oficiais que lá serviam e muita divergência de opiniões. Nenhum de seus integrantes, no entanto, chegou a pegar em armas para combater a revolução.

P.: O peso intelectual dos oficiais das Forças Armadas nas decisões politicas em 1964 era maior do que hoje? O senhor pode justificar?

Gal. Negrão: Não entendi bem a pergunta. O que se entende por "peso inte- lectual"? - Refiro-me ao poder de influenciar nas decisões políticas. - Em 1964 e mesmo em seus antecedentes longínquos, havia um grande envolvimento político dos militares, mas as intervenções eram temporárias e logo havia o retraimento dos militares até a próxima crise. A partir de 1964 e até o fim do governo Figueiredo, as decisões políticas, certas ou erradas, foram dos presidentes-generais. O Presidente Castello tinha uma correta percepção dos riscos desse longo envolvimento e tentou evitálo, mas foi obstado pelos radicais e pelos políticos fardados. Hoje isso não mais existe e a criação do Ministério da Defesa - idéia reformista que Castello não pôde concretizar - facilita isso e deixa bem claro quem são os responsáveis pelas dificuldades $e$ desacertos atuais. O Exército voltou a ser o "grande mudo", embora os revanchistas ainda the atribuam responsabilidades pretéritas que não têm cabimento.

Gal. Ítalo: O peso intelectual dos oficiais do Exército era muito grande nas decisões políticas, pois muitos ocupavam cargos públicos e na legislatura. Hoje o peso é nenhum, pois estão voltados exclusivamente para a sua profissão. Não são nem ouvidos para as decisões importantes como naquela época.

Gal. Justo: Na minha opinião, sim. Naquela época os principais generais da ativa e da reserva remunerada pertenciam a uma geração que tivera participação significativa na vida política do país. Participaram da chamada "Revolta dos Tenentes" na década de 1920 , do movimento que levou Getúlio Vargas ao poder em 1930 e integraram a Força Expedicionária Brasileira. Muitos já haviam exercido cargos de natureza política, inclusive como governadores de importantes estados da Federação. Hoje, devido a imposições regulamentares colocadas em vigor pela própria revolução, os militares estão afastados da política - o que é muito salutar.

P.: Havia crise social, política e econômica (desordens, desabastecimento, caos social) no Paraná antes de 31 de março de 1964? Havia, de fato, o risco de uma iminente e grave perturbação da ordem institucional?

Gal. Negrão: A situação no Paraná era reflexo da situação nacional, como visto nas perguntas 1 e 2 . Aqui havia grande agitação nas áreas estudantil e sindical. Havia alguma inquietação no campo, de 
que a revolta dos posseiros de 1957 fôra um bom exemplo. O Governador Ney Braga era do PDC e contrário politicamente à situação nacional, mas havia em seu governo alguns esquerdistas - os "Ney-boys" - entre eles o vice-Governador Afonso Camargo Neto, Presidente regional do PDC, naquela época fazendo demagogia para agradar a esquerda.

Gal. Ítalo: No Paraná, sob o Governo Ney Braga, tivemos alguns problemas no que diz respeito à posse das terras devolutas. Tudo muito restrito e debelado com energia. Desordem não houve. Não havia risco de perturbação da ordem institucional.

Gal. Justo: Em março de 1964 o Governador do Paraná era o General Ney Braga. Ainda como Major, exercera o cargo de Chefe de Polícia do Estado e em seguida foi eleito Prefeito de Curitiba, oportunidade em que mostrou tratar-se de um político hábil, dinâmico e honesto. Como Governador, vinha atuando com austeridade, modernizando a administração do Paraná e fazendo importantes investimentos, principalmente em estradas, energia elétrica e saneamento básico. Possuía confortável maioria na Assembléia Legislativa e mantinha um relacionamento com as autoridades federais. De um modo geral, a perturbação da ordem, mantida sob controle no Paraná, era ocasionada pelas greves promovidas na área sindical, pela infiltração comunista no meio estudantil e pelas ameaças de uma reforma agrária feita à força.

P.: O senhor poderia descrever o panorama político no Paraná, no início da década de 1960, até 31 de março de 1964?

Gal. Negrão: Em parte respondido no quesito anterior. Como o PCB estava na clandestinidade, seus aderentes militavam em outros partidos, principalmente no PTB. Mas a agitação era feita principalmente nas chamadas "frentes" - hoje seriam as ONGs [organizações não-governamentais] - como demonstro no capítulo "Porque Jango caiu", já citado, e no início do capítulo 4 do outro livro, 1964 - uma revolução perdida [TORRES, 2002, p. 29-36].

Gal. Ítalo: O panorama político do Paraná era influenciado pelo impacto da vitória de Ney Braga quebrando uma hegemonia partidária que vinha desde 1946. O Governador enfrentou muitos problemas, principalmente na área administrativa. Sua tarefa foi muito pesada pelo caos que recebeu de seu antecessor. Como exemplo cito o movimento para criar o estado do Paranapanema, tendo Londrina como capital. Em parte esse movimento tinha razão, pois o Norte do Paraná não tinha ligação com a capital, a não ser por rodovia precária, como a Estrada do Cerne.

Havia os conflitos pela posse da terra não do tipo MST [Movimento dos Trabalhadores Rurais Sem-terra] - mas de capitalistas de São Paulo que conseguiam do governo concessões de grandes áreas de terras devolutas. Ao desalojarem os posseiros de boa-fé, surgiam os conflitos. No que diz respeito a transporte e energia, principalmente, a situação do estado era de dificuldade. Ney teve que criar órgãos importantes para poder agilizar a máquina administrativa.

Gal. Justo: Em março de 1964 eu era um Capitão recém-promovido e tinha a minha atenção voltada mais para os assuntos da área militar. Passados já quarenta anos, não tenho condições de falar com segurança sobre o panorama político e as atividades dos partidos políticos daquela época.

P.: Como era a atividade dos partidos políticos e sindicatos no Paraná até 31 de março de 1964? Após essa data, o que aconteceu?

Gal. Negrão: Tinham toda a liberdade de ação e de opinião. A partir de 31 de março de 1964, houve intervenção em alguns sindicatos, cassações de mandatos de parlamentares comprometidos com a subversão, mas os poderes constituídos continuaram seu funcionamento normal, tendo sido o Paraná um dos estados em que ainda houve eleição direta para Governador em 1965, sendo eleito o candidato governista Paulo Pimentel. A partir de outubro desse ano, com a edição do AI-2, houve a reorganização partidária, com dois partidos só. Para o desdobramento dos acontecimentos ver o capítulo 7 do livro 1964 - uma revolução perdida, "Sementes do AI-5" [TORRES, 2002, p. 47-58].

Gal. Ítalo: Os partidos políticos e os sindicatos tinham uma existência normal. Havia aqueles dominados pelos comunistas, como o dos bancários, que perturbavam um pouco, mas não criavam grandes problemas. Após 1964 houve intervenção em todos os sindicatos e foram nomeados inter- 
ventores, a maioria militares da reserva remunerada do Exército.

Gal. Justo: Considero respondida na questão anterior.

P.: Como o senhor pode descrever os acontecimentos dos dias 31 de março e $1^{\circ}$ de abril de 1964 no Paraná? Houve realmente uma ruptura total da ordem até então vigente?

Gal. Negrão: Após a reunião do Presidente com os sargentos no Automóvel Clube no Rio, sentia-se que algo aconteceria. $\mathrm{O}$ que se passou no Paraná procurei mostrar em meu livro de memórias (capítulos 25, 26 e 27) [TORRES, 1999, p. 79-88]. Não houve ruptura da ordem vigente; a Constituição continuou em vigor, os demais poderes continuaram funcionando: a ruptura foi parcial. O Congresso deu posse ao substituto imediato - o Presidente da Câmara de Deputados - até a eleição pelo próprio Congresso do novo Presidente.

Gal. Ítalo: Não houve ruptura da ordem vigente. O Governador Ney Braga manteve sua estrutura normal, tudo funcionando normalmente. Houve sim muito aplauso e manifestação de apoio ao movimento. Aqui no Paraná a transição do governo civil para o governo militar foi tranqüila, não houve resistência.

Gal. Justo: Os acontecimentos de 31 de março e $1^{\circ}$ de abril de 1964 transcorreram sem maiores sobressaltos no Paraná. O General Dario Coelho, que respondia pelo Comando da $5^{\underline{a}}$ Região Militar, apoiou o movimento desde as primeiras horas e contou com o apoio da quase totalidade da tropa. O Governador do Estado e as principais autoridades políticas também apoiaram a revolução e passaram a colaborar com os comandantes militares. A grande maioria da população mostrava-se aliviada com a queda do regime então existente e mostrava seu contentamento, publicamente. Os que eram contra o movimento não tiveram, portanto, condições de esboçar qualquer reação.

P.: Como a sociedade e a classe política paranaenses reagiram à revolução? Houve algum tipo de resistência civil?

Gal. Negrão: A reação da maioria foi de apoio, pois todos estavam preocupados com os rumos dos acontecimentos. Não houve reação civil. Pouco depois de empossado, o Presidente Castello esteve no Paraná e foi recebido com grandes demonstrações de apoio pela população, tendo desfilado a pé, acompanhado pelo Governador Ney Braga, pela Rua XV [de Novembro].

Gal. Ítalo: A sociedade civil no Paraná, por suas lideranças empresariais, vinha acompanhando com apreensão o que se passava no âmbito do governo federal. Não houve reação, nem resistência.

Gal. Justo: Eu considero respondida na questão anterior

P.: Ocorreram prisões? O senhor se lembra de pessoas influentes na sociedade e na politica que foram presas, na deflagração do golpe?

Gal. Negrão: Ao que eu saiba não houve tais prisões. Como era natural, foram neutralizados aqueles elementos agitadores conhecidos.

Gal. Ítalo: Sim, houve prisões, todas determinadas pelo Exército. - E a Secretaria Estadual de Segurança? - A Secretaria de Segurança, sob o meu comando, efetuavaas e entregava ao Exército. Das pessoas presas julgo as mais importantes o advogado Vieira Neto e o médico Jorge Karam. - Sob que alegação? - A alegação era a de serem simpatizantes do movimento comunista e não concordarem com a revolução.

Gal. Justo: Que eu me recorde, ocorreram poucas prisões e deram-se mais na área sindical. $\mathrm{Na}$ área militar lembro-me da prisão do Comandante do CPOR, Coronel Barcelos, que foi submetido a inquérito, transferido para a reserva e em seguida posto em liberdade.

P.: Houve intervenções nos órgãos públicos, sindicatos etc., cassações e exonerações de ocupantes de cargos públicos no Paraná?

Gal. Negrão: Intervenções em sindicatos, sim. Em órgão estaduais desconheço. Em órgãos federais sim. Um órgão que teve sua direção modificada foi a Rede Ferroviária Paraná-Santa Catarina. Outros que estavam em mãos do PTB ou de pessoas envolvidas em agitação tiveram substituídas as direções. Sobre as cassações há muitas publicações; não tenho dados.

Gal. Ítalo: Como já disse, houve intervenção em todos os sindicatos. O mais visado foi o dos bancários, tendo em vista ser o mais influenciado e dominado pelos comunistas. 
Gal. Justo: Houve intervenção na maioria dos órgãos públicos federais, institutos de aposentadoria e sindicatos. As autoridades mais ligadas ao governo anterior foram afastadas de seus cargos e alguns poucos foram cassados ou aposentados compulsoriamente.

\section{P.: Houve luta armada no Paraná?}

Gal. Negrão: Felizmente, não.

Gal. Ítalo: Não houve luta armada, na acepção da palavra, no Paraná. Não considero a incursão do Coronel Jeferson Cardim como sendo luta armada. Foi um episódio isolado, sendo que no primeiro enfrentamento com as forças legais ele rendeu-se.

Gal. Justo: Não houve luta armada no Paraná, salvo o caso isolado do Coronel Cardim no Sudoeste do Estado, região de Francisco Beltrão. Houve combate em que morreu o Sargento Argemiro de Camargo, das forças regulares.

P.: Houve adesão do governo do estado ao movimento militar?

Gal. Negrão: Sim. O Governador Ney Braga deixou isso registrado em suas memórias.

Gal. Ítalo: O governo Ney Braga aderiu totalmente ao movimento, cumprindo o seu compromisso assumido com os líderes da revolução.

Gal. Justo: Conforme já relatado, o governo do estado aderiu prontamente à revolução.

P.: Como se posicionou a Assembléia Legislativa frente à ruptura da ordem vigente?

Gal. Negrão: Com os naturais protestos dos deputados do PTB e de partidos aliados, aderiu à nova situação. Houve cassações e também não tenho dados.

Gal. Ítalo: A Assembléia Legislativa do Estado do Paraná aguardou com muita expectativa o desdobramento do movimento. Logo após sua eclosão, começaram a ocorrer as cassações de deputados, mesmo aqueles que não eram subversivos, pois eram da linha do governo deposto.

Gal. Justo: A grande maioria dos deputados estaduais concordou com o movimento e aceitou as modificações que ocorreram na área política. Os poucos que discordaram não tiveram capacidade de reagir.
P.: Nos municípios, como se posicionaram os prefeitos e vereadores? Aderiram à revolução ou houve resistência?

Gal. Negrão: Não tenho notícia de reações, a não ser as verbais.

Gal. Ítalo: Nos municípios houve adesão total. Nenhum se posicionando contra, pelo menos em um primeiro momento.

Gal. Justo: A exemplo da Assembléia Legislativa, a quase totalidade dos prefeitos e vereadores aderiu à revolução.

P.: Na opinião do senhor houve arbitrariedades, abuso de poder $e$ descumprimento de direitos constitucionais por parte dos militares, no Paraná?

Gal. Negrão: Certas garantias - como o habeas corpus - foram mantidas até a edição do AI-5, quando foram suspensas para os crimes contra a segurança nacional. Um omelete não se faz sem quebrar os ovos. Após o AI-5 e tendo em vista o recurso ao terrorismo, à guerrilha, aos seqüestros e à violência, tivemos uma guerra interna localizada, mas cruenta. Em uma situação dessa, imaginar que não haja desvios de conduta e arbitrariedades é uma ilusão. Todavia, a institucionalização dos alegados abusos, como a tortura e a eliminação sumária de dissidentes, é uma mentira montada pelos que desencadearam a violência e depois reclamaram de alguns de seus efeitos. Os processos dessa época eram julgados em sessões públicas pela Justiça Militar, com direito a ampla defesa e recurso ao Superior Tribunal Militar. Orientados por seus advogados e dada a dificuldade da prova testemunhal, todos os acusados declararam-se vítimas de tortura e que seus depoimentos, mesmo os voluntariamente feitos de próprio punho, foram obtidos sob coação. O problema é que, por culpa dos vencedores que acreditaram na sinceridade e validade da anistia e de início silenciaram, a história dos chamados "anos de chumbo" foi e ainda está sendo escrita pelos derrotados ou por escribas tendenciosos, com grande repercussão na mídia interessada em sensacionalismo lucrativo ou dominada por gente da esquerda.

Gal. Ítalo: Não houve arbitrariedade alguma. Hoje alegam isso pois está na moda receber indenizações pelo simples fato de terem sido inquiridos em Inquérito PolicialMilitar. Havia uma normalidade constitucional, inclusive com a instituição dos atos 
institucionais. Os militares agiram sempre de acordo com as leis em vigor.

Gal. Justo: Não tive conhecimento de nenhum ato de abuso do poder e descumprimento de direitos constitucionais por parte dos militares. Aconteceram alguns atritos e reclamações a respeito de uma ou outra ação de busca e prisão.

P.: Como era o relacionamento dos militares com a classe politica e a sociedade antes da revolução e imediatamente após?

Gal. Negrão: Em meu entender, nunca houve problemas, exceto com os que queriam implantar no país um regime comunista e com os corruptos. Na época do chamado milagre econômico, o Presidente Médici tinha níveis altíssimos de aprovação nas pesquisas e o próprio Lula sempre reconheceu que nunca o trabalhador brasileiro esteve tão bem como nessa época.

Gal. Ítalo: O relacionamento dos militares no Paraná, com a classe política, era muito bom. Após a revolução começaram a surgir ressentimentos setoriais, o que no meu entender era de se esperar, uma vez que nem todos conformaram-se com a situação.

Gal. Justo: O relacionamento, tanto com a classe política quanto com a sociedade, era muito bom antes e depois da revolução. $\mathrm{O}$ fato de o Governador do Estado ser militar e ter em seu secretariado alguns militares facilitava o relacionamento com a classe política. Naquela época a maioria dos militares que serviam em Curitiba ou eram paranaenses ou casados com mulheres paranaenses, o que facilitava o relacionamento com a sociedade civil.

P.: Com a posse do Marechal Castello Branco na Presidência da República houve modificações no quadro político paranaense?

Gal. Negrão: Não. Ele manteve a eleição programada e por ser o Governador Ney Braga amigo do Presidente, o Paraná passou a ser melhor atendido em suas reivindicações. A solução dada pelo Grupo Executivo de Terras do Sudoeste (GETSOP) para a questão do conflito de terras no Sudoeste é um exemplo.

Gal. Ítalo: A única modificação que houve foi que o Governador Ney Braga foi convocado para ser Ministro da Agricultura, assumindo em seu lugar o Secretário da Fazenda, Algacir Guimarães, eleito que fôra pela Assembléia Legislativa.

Gal. Justo: Com a posse do Marechal Castello Branco na Presidência da República o Paraná fortaleceu-se politicamente. O Governador Ney Braga era muito amigo do Presidente e o estado ganhou o Ministério da Educação e vários cargos nos $1^{\circ} \mathrm{e}$ $2^{\circ}$ escalões da administração federal.

P.: $O$ senhor considera que a atitude de intervir, tomada pela cúpula das Forças Armadas, foi correta?

Gal. Negrão: Se a pergunta refere-se à derru-bada do sr. João Goulart, sim. É o que tenho dito em todas as minhas obras.

Gal. Ítalo: Já se disse, e eu concordo, jamais em toda a sua história o Brasil precisou tanto de suas Forças Armadas, e em particular do Exército, como naqueles decisivos dias em que estava em jogo sua sobrevivência como nação democrática e cristã. Não tenho dúvidas de que a atitude das Forças Armadas foi correta.

Gal. Justo: Sim, se não tivesse havido a intervenção das Forças Armadas naquela oportunidade certamente haveria uma guerra civil, ou seria implantado o regime comunista no país.

P.: No momento dos acontecimentos o senhor aderiu de imediato à causa militar?

Gal. Negrão: Desde o momento em que me convenci de que o movimento era anticomunista e destinado a restabelecer a disciplina e a hierarquia ameaçadas nas Forças Armadas, dei meu apoio e declarei que cumpriria as ordens do General Dario Coelho, rebelado contra o governo Jango.

Gal. Ítalo: Sem dúvida nenhuma.

Gal. Justo: Sim. A partir dos acontecimentos de março de 1964 (comício da Central do Brasil, rebelião dos marinheiros, reunião do Automóvel Clube etc.), passei a fazer parte do grupo de militares que propunham uma intervenção imediata das Forças Armadas.

P.: Qual era a opinião do senhor naquela época a respeito dos acontecimentos políticos que antecederam a revolução (renúncia de Jânio Quadros, parlamentarismo, posse de João Goulart etc.)?

Gal. Negrão: Não votei em Jânio Quadros, pois o sabia um farsante. Na crise da renúncia era aluno de uma escola militar, 
mas tinha quase certeza de que o sr. João Goulart, por incompetência, levaria o país a rumos perigosos - e isso era apenas uma suposição. Aceitei sua posse. Mantive meu compromisso de respeito à autoridade constituída até o momento em que me convenci de que o governo, a que devia lealdade, não a merecia por estar colocando-se progressivamente à margem da lei.

Gal. Ítalo: Inicialmente eu era pela aplicação da lei; infelizmente os acontecimentos tomaram outro rumo e aí o compromisso com a nação era mais importante.

Gal. Justo: A renúncia de Jânio Guadros pegou a população brasileira, inclusive seus auxiliares mais próximos, inteiramente desprevenidos. Os ministros militares não confiavam em João Goulart e consideravam-no despreparado para governar o país em uma situação política tão conturbada. Embora os acontecimentos que se seguiram possam-lhes dar plena razão, os ministros não conseguiram convencer a maioria dos políticos e dos militares. João Goulart acabou assumindo a Presidência da República em um regime parlamentarista. Posteriormente, mediante pressão política, principalmente dos sindicatos, conseguiu que fosse realizado um plebiscito para autorizar o retorno do regime presidencialista. Tais acontecimentos constituíram-se, certamente, em antecedentes que tiveram importante influência no desencadeamento da revolução de 31 de março de 1964.

P.: O senhor poderia fazer algumas considerações finais a respeito do movimento militar de 1964 no Paraná?

Gal. Negrão: É uma simplificação inadequada chamar o movimento de 1964 de "militar". Na realidade - e até a esquerda reconhece isso - as Forças Armadas foram arrastadas por apelo da sociedade, que pedia um "basta!" ao descalabro em que estávamos sendo mergulhados. Basta consultar o que publicava a imprensa nos dias que antecederam ao contra-golpe de 1964. Para o Paraná, especialmente, a revolução modernizadora em que o movimento transformou-se foi altamente benéfica. Nunca o Paraná teve tanta representatividade nos altos escalões da República e recebeu tantos benefícios. Estes não foram maiores porque, infelizmente, por motivos internos e externos, o esforço de modernização e desenvolvimento iniciado no governo Castello Branco sofreu solução de continuidade e mesmo as grandes reformas feitas por ele não persistiram ou não tiveram seguimento.

Gal. Ítalo: Repito que o Brasil nunca, na sua história, precisou tanto de suas Forças Armadas como naqueles dias de 1964. Estava em jogo a própria sobrevivência do Brasil como nação democrática e cristã, daî a razão de considerar correta a atitude dos chefes militares. Para o Paraná a revolução foi positiva, uma vez que o Governador era oriundo do meio militar e isso favoreceu o entendimento com o governo federal, trazendo muitos benefícios para o estado.

Gal. Justo: Durante os vinte anos em que os militares estiveram no poder foram cometidos muitos erros, principalmente na área política. Os benefícios que proporcionaram a toda a população brasileira foram, no entanto, muito maiores. Impediram que fosse implantado no Brasil, contra a vontade da maioria da população, o regime comunista. Nas décadas de 1960 e 1970 o país viveu um período de grande desenvolvimento, com aumento da renda per capita, do número de empregos e da realização de importantes obras de infraestrutura; modernização e ampliação acelerada dos meios de comunicações; amplos benefícios sociais, tais como a criação do FGTS [Fundo de Garantia por Tempo de Serviço], do PIS-PASEP [Programa de Integração Social-Programa de Formação do Patrimônio do Servidor Públicol e do $\mathrm{BNH}$ [Banco Nacional de Habitação]; modernização da administração pública, principalmente por meio do Decreto-Lei n. 200.

$\mathrm{O}$ excessivo número de intervenções em órgãos públicos e sindicatos eu acho que desgastou muito os militares; não que se tenham locupletado com o cargo, mas muitos não estavam preparados para aquilo. Houve também muita ingerência de comandantes de organizações militares em assuntos políticos sem que para isso estivessem preparados nem sequer autorizados. A opção pela luta armada não foi, como muitos querem pregar, uma forma de as esquerdas defenderem-se do endurecimento do regime pela edição do AI-5 e por outras medidas, pois muito antes dessas medidas já sofríamos atentados, como por exemplo o ataque ao Hospital Militar de São Paulo e outras ações inclusive psicológicas de ameaças de atentados e 
seqüestros de familiares de militares. O endurecimento do regime foi uma medida necessária naquele momento pela situação que as Forças Armadas estavam vivendo e devido ao risco de implantação do terror por parte das esquerdas radicais.

\section{CONCLUSÃO}

A revolução de 1964 foi um movimento gestado na cúpula militar que, pelas características da instituição militar (hierarquia e disciplina), obteve a adesão rápida e quase unânime dos comandantes militares em todos os níveis e da tropa.

É difícil estabelecer características ou motivações locais para o golpe; não aconteceram revoluções regionalizadas, o movimento foi uno e indiviso. Percebe-se que a opinião dos entrevistados coincide com o que já disseram os líderes do movimento. Com exceção de alguns acon- tecimentos pontuais, o golpe de 1964 foi uniforme e de amplitude nacional, o que, sem dúvida, foi a razão da vitória dos militares.

A análise das entrevistas realizadas com os militares demonstra uma convergência das opiniões, salvo pequenos detalhes que caracterizam a visão pessoal de cada entrevistado acerca de determinados fatos. Observa-se que o enfoque geral é praticamente o mesmo. É importante destacar que as entrevistas foram realizadas individualmente, sem que um tivesse tido contato com as respostas dos outros - nem ao menos um sabia que os outros haviam respondido as mesmas questões. Essas coincidências parecem demonstrar que a idéia do golpe estava impregnada no pensamento dos oficiais como sendo algo necessário e constituía-se naquele momento como um dever dos militares para com a pátria a que eles não poderiam faltar.

José Carlos Dutra (dutra.pr@terra.com.br) é graduado em Geografia e Direito pela Universidade Estadual de Ponta Grossa (UEPG) e aluno do Curso de Especialização em Sociologia Política da Universidade Federal do Paraná (UFPR).

\section{REFERÊNCIAS BIBLIOGRÁFICAS}

ESTEVES, D. (comp.). 1996. Documentos históricos do Estado-Maior do Exército. Brasília : Estado-Maior do Exército.

TORRES, R. N. 1998. Nos “porões” da ditadura. Rio de Janeiro : Expressão e Cultura.
1999. Meninos, eu "também" vi! $2^{\mathrm{a}}$ ed. Curitiba : $\mathrm{s} / \mathrm{n}$

1964. Uma revolução perdida. Curitiba : Torre de Papel.

\section{OUTRASFONTES}

Relatório da $5^{a}$ Região Militar e $5^{a}$ Divisão de Infantaria concernente ao movimento militar de 31 de março de 1964. 1964. Curitiba : digit.
Boletins diários ostensivos do Comando da $5^{a}$ Região Militar e $5^{a}$ Divisão de Infantaria. 1964. Curitiba, mar.-abr. e maio. 